OPEN ACCESS

Edited by:

Enrico M. Clini

University of Modena and Reggio

Emilia, Italy

Reviewed by:

Fabrizio Luppi,

University of Milano Bicocca, Italy

Bruno Balbi,

Fondazione Salvatore Maugeri,

Veruno (IRCCS), Italy

*Correspondence: Jennifer Mann

jennifer.mann@austin.org.au

Yet Hong Khor

yethong.khor@austin.org.au

Specialty section:

This article was submitted to

Pulmonary Rehabilitation,

a section of the journal

Frontiers in Rehabilitation Sciences

Received: 02 August 2021

Accepted: 20 September 2021

Published: 18 October 2021

Citation:

Mann J, Goh NSL, Holland AE and Khor YH (2021) Cough in Idiopathic

Pulmonary Fibrosis.

Front. Rehabilit. Sci. 2:751798.

doi: 10.3389/fresc.2021.751798

\title{
Cough in Idiopathic Pulmonary Fibrosis
}

\author{
Jennifer Mann ${ }^{1,2,3 *}$, Nicole S. L. Goh ${ }^{1,2,3}$, Anne E. Holland ${ }^{2,4,5}$ and Yet Hong Khor ${ }^{1,2,3 *}$ \\ ${ }^{1}$ Department of Respiratory and Sleep Medicine, Austin Health, Melbourne, VIC, Australia, ${ }^{2}$ Institute for Breathing and Sleep, \\ Melbourne, VIC, Australia, ${ }^{3}$ Department of Medicine (Austin Health), University of Melbourne, Melbourne, VIC, Australia, \\ ${ }^{4}$ Department of Physiotherapy, Alfred Health, Melbourne, VIC, Australia, ${ }^{5}$ Central Clinical School, Monash University, \\ Melbourne, VIC, Australia
}

Chronic cough is experienced by most patients with idiopathic pulmonary fibrosis (IPF). It is often the first symptom and is associated with reduced quality of life, increased rates of depression and anxiety, more severe physiological impairment, and disease progression. Although not fully understood, recent gains in understanding the pathophysiology of chronic cough in IPF have been made. The pathophysiology is likely multifactorial and includes alterations in mucous production and clearance, architectural distortion, and increased cough reflex sensitivity, suggesting a role for targeted therapies and multidisciplinary treatment. Modifiable comorbidities can also induce cough in patients with IPF. There is a renewed emphasis on measuring cough in IPF, with clinical trials of novel and repurposed therapies for chronic cough emerging in this population. This review provides an update on the clinical characteristics, pathophysiology, and measurement of chronic cough in patients with IPF and summarizes recent developments in non-pharmacological and pharmacological therapies.

Keywords: cough, idiopathic pulmonary fibrosis, interstitial lung disease, quality of life, patient reported outcome (PRO) measures, prognosis

\section{INTRODUCTION}

Idiopathic pulmonary fibrosis (IPF) is a chronic fibrosing idiopathic interstitial pneumonia, most prevalent after the 6th decade of life. It is associated with significant morbidity and mortality, with progressive worsening of respiratory symptoms over time. Cough is a common symptom, often occurring years prior to diagnosis, contributing to poor prognosis and reduced quality of life. The severity of cough encompasses its frequency, intensity, and impact to patients' lives (1). Cough frequency is an objective measurable index, which is commonly expressed as absolute cough counts and number of coughs per hour. In the absence of a gold standard measuring cough intensity, or the force of cough, it has been assessed objectively using physiological measures such as expiratory flow in research settings, and subjectively using patient reported instruments for its impact. Along with accurate assessment of cough severity, improved understanding of the pathophysiological mechanisms and contributors to cough, and development of evidence-based management are vital to improve quality of life in patients with IPF. 


\section{COUGH CHARACTERISTICS}

\section{Epidemiology and Demographics}

Cough and dyspnoea are the two most common symptoms described in patients with IPF, with up to $80 \%$ experiencing chronic cough (2). Cough is often the first symptom and may precede diagnosis by months to years. Female gender and neversmoking status are associated with increased cough frequency in patients with IPF measured objectively by 24 -h cough recording (3). Unexpectedly, smoking history is the strongest predictor of cough in IPF, with current or ex-smokers less likely to report cough (2). Smokers have reduced cough counts in response to capsaicin provocation when compared to non-smokers. Possible mechanisms include nicotine-induced inhibition of $\mathrm{C}$ fibers, changes in mucociliary clearance or desensitization of cough receptors in airway epithelium (4).

Cough is more prevalent in patients with advanced IPF (2). Increased cough frequency measured by mean coughs per hour have been associated with reduced exercise tolerance and higher serum levels of Krebs von den Lungen 6 molecule (5), a marker of alveolar epithelial cell injury currently under evaluation as a prognostic biomarker in IPF. In a cohort of 242 patients with IPF, the presence of cough was an independent predictor of disease progression, defined as a $15 \%$ decline in the diffusing capacity of the lungs for carbon monoxide, a $10 \%$ decline in forced vital capacity, lung transplantation, or all-cause mortality (2). Despite this, further evidence is required to conclusively demonstrate the relationship between cough and disease progression in patients with IPF.

\section{Cough Description and Impacts}

Cough due to IPF is typically described as dry or non-productive and refractory to antitussive therapy. A minority of patients have a chesty cough from the onset of disease. The severity of cough in IPF is greater than in other types of interstitial lung disease (ILD) (6-8). The intensity of cough increases significantly before death, although less markedly than for dyspnoea (9). Using 24 -h objective cough frequency monitoring, diurnal variation is observed in IPF-related cough (10). The median daytime cough counts are 14.6-25 per hour compared to the median night-time cough counts of 1.9-9 per hour, although there are wide interindividual variations $(10,11)$. This diurnal variation is possibly related to the inhibition of cough by cortical pathways at night.

Patients identify cough as a key symptom associated with physical and emotional distress, with a more limited appreciation by health care professionals (12). Physical symptoms associated

Abbreviations: ATAQ-IPF-cA, A Tool to Assess QOL in IPF Cross Atlantic; CASA-Q, Cough and Sputum Assessment Questionnaire; CQLQ, Cough Quality of Life Questionnaire; CPAP, Continuous positive airway pressure; FVC, Forced vital capacity; GOR, Gastroesophageal reflux; ICC, Intraclass correlation coefficient; L-IPF, Living with IPF Questionnaire; ILD, Interstitial lung disease; IFN, Interferon; IPF, Idiopathic pulmonary fibrosis; LCQ, Leicester Cough Questionnaire; MID, Minimally important difference; MUC5B, Mucin 5B; NGF, Nerve growth factor; OSA, Obstructive sleep apnoea; PRO, Patient reported outcome; PROM, Patient reported outcome measure; SGRQ-I, IPF-specific version of St George's Respiratory Questionnaire; TL $\mathrm{CO}_{\mathrm{CO}}$, Transfer factor for carbon monoxide; VAS, Visual analog scale.

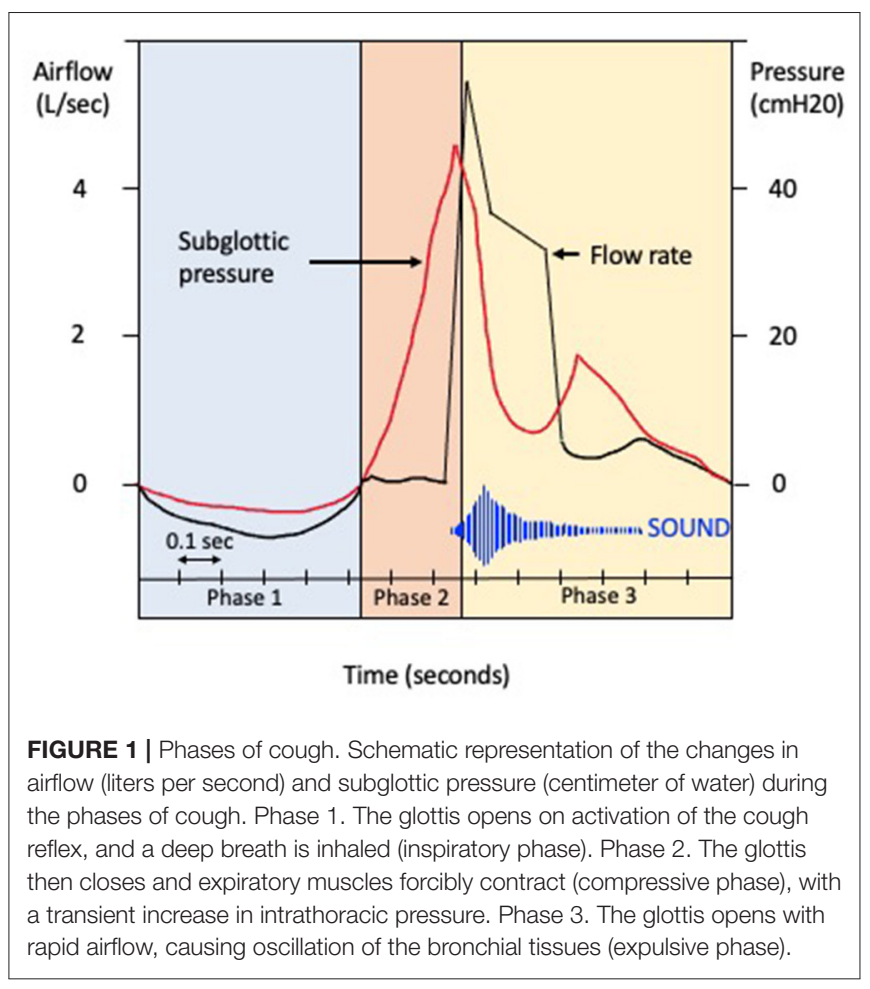

with cough include chest pain, light-headedness, cough-related syncope, hoarse voice, incontinence, and sleep disturbance (1, 13). Severe cases may cause vomiting and even rib fractures (14). Some patients experience cough evoking spells of severe breathlessness and anxiety. The psychosocial effects of IPFrelated cough are generally under-recognized (12), although they can cause disruption to work and social activities, tensions in relationships, and embarrassment. Management of IPF-related cough often involves trying different therapies with limited effects, which can be frustrating for patients and clinicians (15). Similarly, caregivers for patients with IPF report specific concerns regarding the need for guidance around symptom monitoring for cough (16). Thus, it is essential to assess for the presence and impact of cough in patients with IPF to enable focused intervention to address patients' needs.

\section{PATHOPHYSIOLOGY}

Coughing is an important defensive reflex that enhances clearance of secretions and particulates from airways and prevents aspiration of foreign materials. It is now accepted that there is also an element of behavioral voluntary control (17). There are three phases of a cough (Figure 1): the initial deep inspiration, compression of intrathoracic air due to forced exhalation against a closed glottis, and the final expiration with glottic release (18). The cough reflex (Figure 2) is triggered via rapidly adapting receptors, slowly adapting stretch receptors, and c-fibers in the afferent pathway that conduct mechanoreceptor and chemoreceptor stimuli to the medullary control center by branches of the vagus nerve (20). Cough receptors are most 


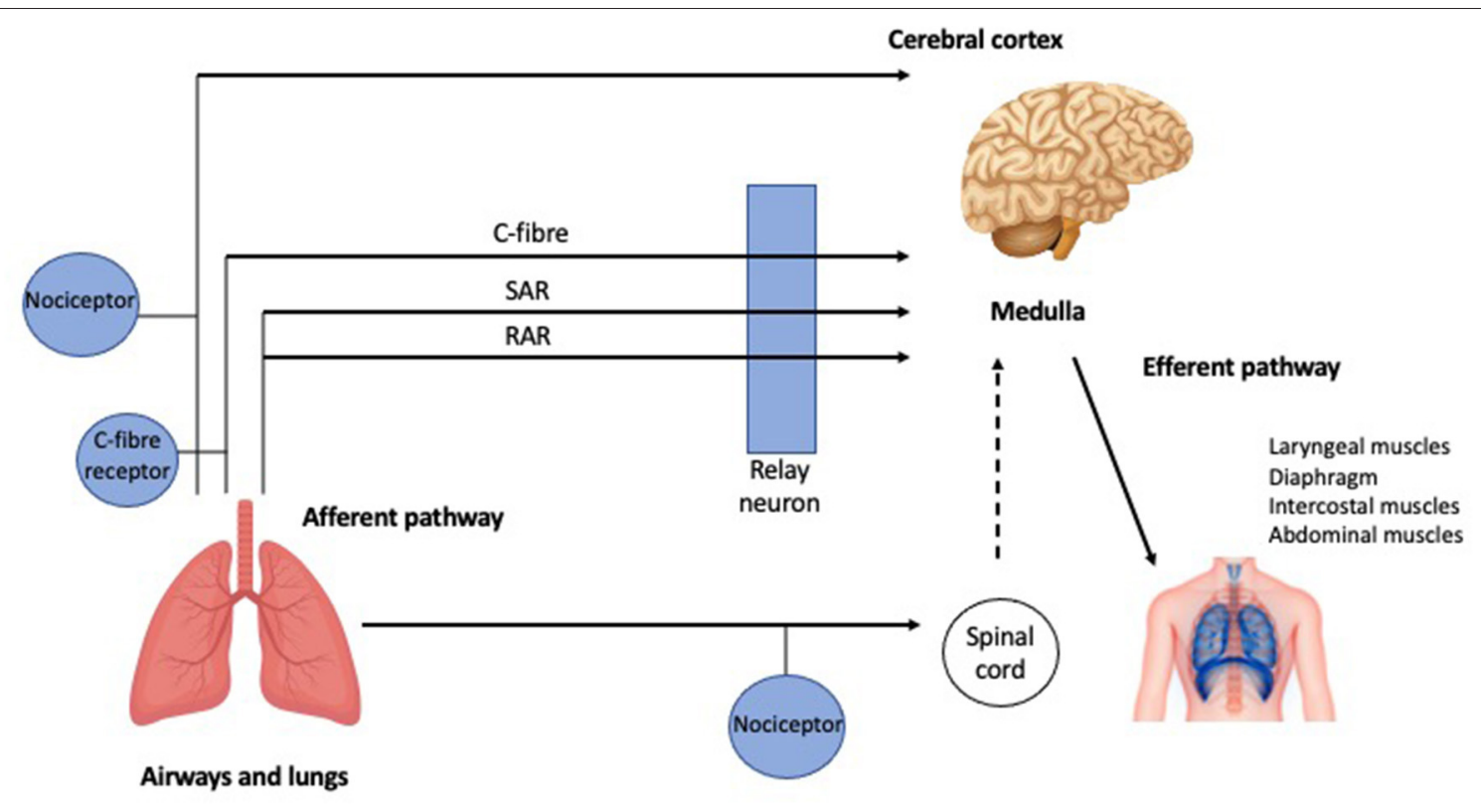

FIGURE 2 | The cough reflex. Schematic representation of the afferent and efferent pathways of the cough reflex (further detail in the text). RAR, Rapidly adapting receptors; SAR, slowly adapting stretch receptors [adapted from Mazzone (19) with permission from Elsevier].

concentrated in upper airways, but also present in distal airways and lung parenchyma (21). Efferent signals are carried to the diaphragm via the phrenic nerves, to the abdominal muscles via the spinal motor nerves, and to the larynx via the laryngeal branches of the vagus nerve (21). While the pathophysiology of chronic cough in IPF is not fully understood, the most accepted theories propose multifactorial causation, including mechanical, chemical, and biological factors.

\section{Mechanical Distortion}

Hallmarks of lung parenchymal damage in IPF include architectural distortion with volume loss and traction bronchiectasis. There are a number of theories as to how mechanical distortion might result in the development of cough in IPF, although none are proven. Mechanical stress from fibrotic tissue "pulling apart" the small airways may contribute to cough in IPF by sensitizing rapidly adapting receptors within the peripheral airways (22), thereby lowering the cough threshold. It has also been postulated that the loss of healthy lung tissue may destroy inhibitory nerves involved in the cough reflex (23). External percussion of the chest wall has been shown to induce cough in patients with IPF, particularly when lung bases, the part most affected in IPF, is stimulated (24). Total cough count in response to mechanical stimulation correlates with subjective measures of cough severity, including the Visual analog scale (VAS), Leicester Cough Questionnaire (LCQ), and Cough Symptom Score (24). Similarly, vibration caused by talking may increase mechanical stimulation of sensory receptors in this population (24). There is interest in cough as an additional source of mechanical stretch, contributing to a pro-fibrotic feedback loop. Mechanical tissue stretch has been shown to activate transforming growth factor-beta 1, a key profibrotic cytokine that has been implicated in the development of pulmonary fibrosis in animal models (25). In other words, cough may beget cough, becoming a self-perpetuating vicious cycle. If proven, this may explain why cough can be associated with disease progression in IPF (2). Cough as a driver of disease progression (26) requires exploration, focusing on mechanisms of stretch injury to alveoli at the lung periphery (27).

\section{Enhanced Cough Reflex}

Patients with IPF demonstrate a heightened cough reflex response to capsaicin (28) and substance $P$ with an increased urge to cough, compared to healthy individuals (29). This response is reproducible and likely related to the underlying disease process (29), although the exact mechanism remains unclear. The absence of change in the capsaicin-induced cough sensitivity in simulated lung volume restriction in healthy individuals by chest strapping supports the presence of altered cough reflex in patients with IPF, independent of ventilatory defects (28). Inflammatory mediators activate cough receptors acutely, but recent progress in the pathogenesis of chronic cough suggests an additional role in neuroplasticity through the production and release of neurotrophins (17). Neurotrophins are proteins that induce the survival, development, and function of different groups of sensory nerves, which can alter and augment cough reflex sensitivity (28). Immunohistochemical studies have demonstrated enhanced expression of the neurotrophins nerve growth factor (NGF) and brain-derived neurotrophic factor in lungs affected by IPF compared to controls. Increased levels of NGF have also been found in induced sputum samples from patients with IPF compared to controls (22), with upregulation of messenger ribonucleic acid for NGF in alveolar macrophages 
TABLE 1 | Comorbid conditions associated with chronic cough in patients with IPF.

\begin{tabular}{|c|c|c|c|}
\hline System & Diagnosis & Proposed mechanisms of cough & Prevalence in IPF \\
\hline \multirow[t]{5}{*}{ Respiratory and sleep } & $\begin{array}{l}\text { Infection: tuberculosis, pertussis, lung abscess, } \\
\text { protracted bacterial bronchitis }\end{array}$ & $\begin{array}{l}\text { Excess mucous production, loss of ciliary structure, } \\
\text { airway inflammation }\end{array}$ & $\mathrm{NA}^{*}$ \\
\hline & $\begin{array}{l}\text { Chronic obstructive pulmonary disease, } \\
\text { bronchiectasis }\end{array}$ & Excess mucous production, C-fiber nerve activity & $6-67 \%(37)$ \\
\hline & Asthma & Bronchial hyperreactivity & $8.5-18.6 \%(38)^{\dagger}$ \\
\hline & Lung cancer & C-fiber nerve activity & $10-30 \%(39)$ \\
\hline & Obstructive sleep apnoea & $\begin{array}{l}\text { Upper airway inflammation and injury due to airway } \\
\text { obstruction }\end{array}$ & $22-90 \%(40)$ \\
\hline \multirow[t]{3}{*}{ Ear nose and throat } & Earwax or foreign body & $\begin{array}{l}\text { Stimulation of branch of the vagal nerve innervating } \\
\text { external auditory canal }\end{array}$ & NA \\
\hline & Chronic sinusitis & $\begin{array}{l}\text { Direct irritation of the vocal cords, sensitization of } \\
\text { the cough reflex }\end{array}$ & NA \\
\hline & Vocal cord dysfunction & $\begin{array}{l}\text { Paradoxical vocal cord movement and glottis } \\
\text { closure with airway narrowing }\end{array}$ & NA \\
\hline Gastrointestinal & Gastro-esophageal reflux disease & $\begin{array}{l}\text { Microaspiration and direct irritation, sensitization of } \\
\text { the cough reflex due to activation of vagal nerve } \\
\text { endings in the esophagus }\end{array}$ & $87-94 \%(41-44)^{\ddagger}$ \\
\hline \multirow[t]{2}{*}{ Cardiovascular } & Left ventricular failure & $\begin{array}{l}\text { Pulmonary c-fibers activated by pulmonary venous } \\
\text { congestion and oedema ( } 45)\end{array}$ & $4-26 \%(37)$ \\
\hline & Arrhythmia & $\begin{array}{l}\text { Mediators of cough (bradykinin and substance } P \text { ) } \\
\text { accumulate in the upper airway }\end{array}$ & $N A^{\S}$ \\
\hline Drugs/toxins & Angiotensin-converting enzyme inhibitor use & $\begin{array}{l}\text { Mediators of cough (bradykinin and substance } P \text { ) } \\
\text { accumulate in the upper airway }\end{array}$ & $N A^{\mathbb{I}}$ \\
\hline
\end{tabular}

IPF, idiopathic pulmonary fibrosis; NA, not available; TB, tuberculosis.

${ }^{\star}$ Incidence of TB 6.3\% (46) in an observational study of 143 patients in South Korea.

${ }^{\dagger}$ Asthma diagnosed in the year prior to IPF diagnosis.

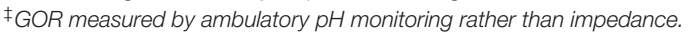

$\S$ In a retrospective study of patients who underwent lung transplantation for IPF, the incidence of atrial arrhythmia was $25.4 \%$ in 366 patients (47).

INote in the ASCEND (48) and CAPACITY (49) studies 111 of 624 patients with IPF were on an Angiotensin-converting enzyme (ACE) inhibitor at randomization (50).

sampled with bronchoalveolar lavage (30). Patients with IPF have sputum eosinophilia and increased sputum eosinophilic cationic protein concentration compared to normal controls (31), raising the possibility that eosinophils may modulate the cough reflex by increasing the presence of $G$ protein-coupled receptor and substance $\mathrm{P}$ in human airway nerves (32).

\section{Change in Mucous Production}

While the exact pathogenesis of IPF is yet to be elucidated, genetic variation is an established risk factor for its development. A common variant in the promoter region of the mucin $5 \mathrm{~B}$ (MUC5B) gene, the most well-validated genetic risk factor for IPF (33-35), increases production of MUC5B, an airway mucin. The presence of the minor allele of the MUC5B promoter polymorphism (rs35705950) correlates with a clinical phenotype of IPF characterized by more severe cough (36), which is independent of age, gender, and secondary causes of cough.

\section{ROLE OF COMORBIDITIES}

IPF-related comorbidities and other health conditions can be important contributors to cough in this population and are therefore key targets for treatment. Table 1 summarizes common remedial conditions associated with chronic cough and conditions not to be missed. Careful evaluation is required to diagnose and address these comorbidities. In particular, patients with IPF are at increased risk for lung cancer with adverse impacts on survival (51). Gastroesophageal reflux (GOR) and obstructive sleep apnoea (OSA) are two common comorbidities associated with cough and are discussed in more detail below.

\section{Gastroesophageal Reflux}

The role of GOR in IPF remains unsettled, with inconclusive results on therapeutic effects of antacid medication and antireflux surgery on progression-free survival, quality of life, and all-cause mortality in this population $(41,52)$. As distinct from acid reflux, the presence of hiatus hernia has been more clearly associated with disease progression and mortality (53). GOR is a well-accepted contributing factor to chronic cough in the general population and is included in chronic cough assessment and treatment algorithms. Patients with GOR-associated cough may not report typical symptoms such as heartburn, which are mediated by the spinal pathways, and not the vagus nerve.

The prevalence of GOR is higher in IPF than in other chronic lung diseases $(42,54,55)$ and the general population (56). Eighty-seven to ninety-four percent of patients with IPF have evidence of reflux measured by ambulatory $\mathrm{pH}$ monitoring, even in the absence of symptoms (43) and despite treatment with acid-suppressive therapies. Cough frequency does not improve despite verifiable reductions in esophageal acid exposure, as 
non-acid reflux may remain or worsen with antacid medication (44). In addition to causing cough, reflux has been proposed to drive the perpetuation of fibrosis with inflammation and injury secondary to recurrent micro-aspiration. In animal models of IPF, pulmonary fibrosis was induced by direct instillation of acid into the airways (57).

Substance $P$ and mast cell-tryptase are both elevated in the sputum of patients with chronic cough and comorbid GOR, which inversely correlate with cough threshold (58). In patients with IPF, salivary pepsin, a marker of proximal GOR, is higher in those with daily cough compared to those with infrequent cough (59). Both acid and non-acid events contribute to lung inflammation and fibrosis (60), suggesting that even in those patients on antacid medication, non-acid events may perpetuate the cycle of inflammation. Additionally, the long-term use of proton pump inhibitors has been associated with higher rates of respiratory infection and other side effects, including fracture risk and nutritional deficiencies $(52,61,62)$. Thus, in the absence of proven or symptomatic reflux, empirical use of antacid medication is not currently recommended (63).

\section{Obstructive Sleep Apnoea}

Sleep-disordered breathing, including OSA and sleep-related hypoxaemia, are increasingly recognized as important clinical features in IPF. The prevalence of OSA increases with age, which overlaps with that of IPF, and severity plateaus around the age of 65 in patients with stable body mass index (64). The exact prevalence of OSA (defined as an apnoea-hypopnoea index $\geq 5$ ) in IPF is difficult to establish, with a wide range of values [22-90\% (40)] due to the small number of participants in many studies. Most studies report higher apnoea hypopnoea index in patients with IPF than that of the general population (65).

The relationship between sleep-disordered breathing and cough in IPF has only been investigated in a limited number of studies. OSA is a recognized remedial cause of chronic cough in the non-IPF population (66) and responds to treatment with continuous positive airway pressure (CPAP). There are no studies that measure the effect of CPAP on cough in patients with IPF using objective cough monitors or cough-specific questionnaires. Rather, in a study of 12 patients with newly diagnosed IPF and moderate-to-severe OSA, $48 \%$ of patients complained of nocturnal cough during treatment with CPAP (67). Some patients with IPF are intolerant of CPAP and experience claustrophobia associated with a rapid and shallow breathing pattern and cough $(67,68)$. Additionally, cough can be exacerbated by dry air during CPAP initiation, which may be addressed using heated humidification. CPAP has been shown to improve sleep and quality of life in patients with IPF and comorbid OSA (69) and there may be a role for a trial of CPAP to address cough in patients with nocturnal cough. An acclimatization period with CPAP at lower pressures and intense clinician follow-up may be of benefit.

\section{EVALUATION}

Chronic cough is a significant challenge for the treating clinician and healthcare team, particularly in IPF where it is often refractory to antitussive therapy. A systematic approach to evaluation, starting with clinical assessment for cough characteristics, comorbidities, and non-IPF causes of cough is necessary. While well-accepted in clinical research and multidisciplinary cough clinics, cough measurement has not yet been incorporated into routine clinical practice. Nevertheless, it is an important step in assessing severity, response to treatment, and as a communication tool for patients and caregivers.

\section{Clinical Assessment}

In patients with IPF who present with a troublesome cough, a timely and thorough history-taking, clinical examination, basic blood workup, chest radiograph and lung function testing is recommended. An attempt should be made to distinguish IPF-related cough from non-IPF-related cough (63). A sudden worsening of symptoms or significant deterioration in forced vital capacity (FVC) or transfer factor for carbon monoxide $\left(\mathrm{TL}_{\mathrm{CO}}\right)$ on lung function testing may prompt further investigation with computed tomography of the chest to assess for acute exacerbation, infection, or disease progression. Red flag symptoms for lung cancer include haemoptysis, dysphonia or dysphagia, and weight loss. Relevant comorbidities (Table 1) should be actively considered, and treatment trials or further clinical investigations should be pursued according to clinical assessment. Some examples include nasolaryngoscopy for sinus and upper airway pathology, polysomnography for sleep-disordered breathing and impedance testing for silent GOR.

\section{Objective Cough Measurement}

Cough severity can be objectively measured in a number of ways. Cough frequency and cough reflex sensitivity are the two most commonly used in research settings, with a growing interest in measuring the force or intensity of coughing. Cough monitors measure cough frequency using an external microphone that records patients' cough for extended periods of $\geq 24 \mathrm{~h}$. VitaloJAK (Vitalograph Ltd, Buckingham, UK) and the Leicester cough monitor are two validated monitors $(70,71)$, which have been used for research. Cough reflex sensitivity is assessed by the controlled inhalation of protussive compounds such as capsaicin and citric acid. Capsaicin is the most used agent, with a proven safety profile and predictable and repeatable dose-response (28, 72) in patients with IPF. Measurement of cough reflex sensitivity is often used in early phase studies to prove engagement of a drug molecule with its target, as well as to measure the ability to suppress cough using antitussive therapies (73). It is not yet practical to measure the intensity of cough objectively in clinical settings. Potential techniques include pneumotachography for expiratory airflow measurement, electromyography studies of the respiratory muscles, and measurement of transdiaphragmatic pressures (74), which are yet to be evaluated in patients with IPF. Cough intensity may be particularly relevant in this population, given the suggested pathophysiological role of mechanical stretch in augmenting the activation of profibrotic mechanisms. 
TABLE 2 | Summary of measurement properties of PROMs for cough assessment in IPF.

\begin{tabular}{|c|c|c|c|c|}
\hline $\begin{array}{l}\text { Measurement } \\
\text { tool }\end{array}$ & References & Population & $\begin{array}{l}\text { Psychometric } \\
\text { properties }\end{array}$ & Results \\
\hline \multicolumn{5}{|c|}{ Cough-specific instruments } \\
\hline \multirow[t]{4}{*}{ LCQ } & \multirow[t]{2}{*}{ Key et al. (11) } & 19 participants with IPF & \multirow[t]{2}{*}{ Construct validity } & \multirow{2}{*}{$\begin{array}{l}\text { Spearman's correlation coefficients for objective cough } \\
\text { frequency and LCQ total } r-0.80(p<0.001) \text { and LCQ } \\
\text { physical } r 0.76(p<0.001)^{\star}\end{array}$} \\
\hline & & DLCO $\% 43.2 \pm 16.06$, FVC $\% 78.5 \pm 24.4$ & & \\
\hline & \multirow[t]{2}{*}{ Morice et al. (77) } & $\begin{array}{l}45 \text { participants ( } 29 \text { with IPF) } \\
\text { TLCO } \% 49 \pm 16\end{array}$ & Construct validity & $\begin{array}{l}\text { Correlations between LCQ domains and measures of } \\
\text { disease severity were weak and non-significant. }\end{array}$ \\
\hline & & & Test-retest reliability & $\begin{array}{l}\text { ICCs for total and domain scores ranging from } \\
0.37 \text { to } 0.58\end{array}$ \\
\hline \multirow[t]{2}{*}{ VAS } & \multirow[t]{2}{*}{ Key et al. (11) } & $\begin{array}{l}19 \text { participants with IPF } \\
\text { DLCO } \% 43.2 \pm 16.06, \text { FVC } \% 78.5 \pm 24.4\end{array}$ & \multirow[t]{2}{*}{ Construct validity } & $\begin{array}{l}\text { Spearman's correlation coefficients for objective cough } \\
\text { frequency and VAS for cough severity }{ }^{\star}\end{array}$ \\
\hline & & & & $\begin{array}{l}\text { Day cough rate } r=0.8(p<0.001) \text { and night cough rate } \\
r=0.71(p=0.001) .\end{array}$ \\
\hline \multirow[t]{3}{*}{ CQLQ } & \multirow[t]{3}{*}{ Lechtzi et al. (78) } & 20 participants with IPF & Internal consistency & Cronbach's a $>70$ for total score and $4 / 6$ subscales \\
\hline & & DLCO $\% 57.4 \pm 14.4$, FVC\% $70.4 \pm 13.7$ & Test-retest reliability & $\begin{array}{l}\text { ICC for total score at baseline and week } 150.88 \\
(p<0.01)\end{array}$ \\
\hline & & & MID & MID was 5.7 (95\% Cl, 4.9-6.4) \\
\hline \multirow[t]{3}{*}{ CASA-Q } & \multirow[t]{3}{*}{ Gries et al. (79) } & $\begin{array}{l}18 \text { participants with IPF } \\
\text { DLCO } \% 48.7 \pm 15.1, \text { FVC } \% 87.2 \pm 30.7\end{array}$ & \multirow[t]{3}{*}{ Content validity } & $\begin{array}{l}{ }^{\dagger} \text { Intended meaning of each item clearly understood } \\
\text { (89-100\%). }\end{array}$ \\
\hline & & & & Items perceived to be highly relevant \\
\hline & & & & Recall period accurately used $89 \%$. \\
\hline \multicolumn{5}{|c|}{ Disease-specific instruments with cough domains or items relevant to cough } \\
\hline \multirow[t]{2}{*}{ ATAQ-IPF } & \multirow[t]{2}{*}{ Horton et al. (80) } & 95 participants with IPF & \multirow[t]{2}{*}{ Internal consistency } & \multirow[t]{2}{*}{ †Cronbach's a 0.92, Rasch model reliability 0.83} \\
\hline & & DLCO $\% 39 \pm 15$, FVC\% $65 \pm 17$ & & \\
\hline \multirow[t]{3}{*}{ ATAQ-IPF-cA } & \multirow[t]{3}{*}{ Birring et al. (81) } & 139 participants with IPF & \multirow[t]{2}{*}{ Construct validity } & \multirow[t]{2}{*}{ Two items were removed due to floor effects } \\
\hline & & DLCO $\% 42.2 \pm 11.9-43.2 \pm 16.5$ & & \\
\hline & & FVC $\% 70.1 \pm 17.7-80.7 \pm 9.2^{\ddagger}$ & Internal consistency & †Internal consistency Cronbach's a 0.92 \\
\hline \multirow[t]{3}{*}{ L-IPF } & \multirow[t]{3}{*}{ Swigris et al. (82) } & $\begin{array}{l}125 \text { participants with IPF } \\
\text { DLCO } \% 50 \pm 20, \text { FVC } \% 71 \pm 20\end{array}$ & Construct validity & $\begin{array}{l}\text { Correlation between L-IPF cough domain and SGRQ } \\
\text { symptom domain } 0.67 \text {. Correlations between L-IPF } \\
\text { domain for cough and disease severity significant. }\end{array}$ \\
\hline & & & Internal consistency & ${ }^{\dagger}$ Internal consistency $\omega$ coefficient $>0.93$ \\
\hline & & & Test-retest reliability & ${ }^{\dagger} \mathrm{ICC} 0.85$ \\
\hline \multirow[t]{2}{*}{ SGRQ-I } & \multirow[t]{2}{*}{ Prior et al. (83) } & 150 participants with IPF & Internal consistency & †Cronbach's a 0.77 \\
\hline & & DLCO $\% 48.4 \pm 14.1$, FVC\% $87.2 \pm 23.1$ & Test-retest reliability & ${ }^{\dagger} \mathrm{ICC} 0.78$ \\
\hline
\end{tabular}

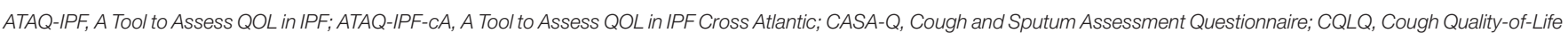

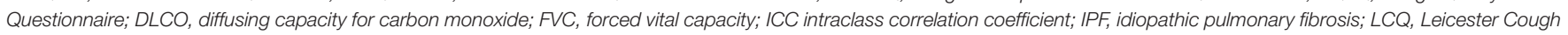

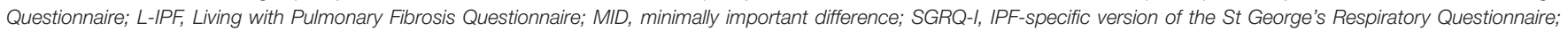
TLCO, transfer factor for carbon monoxide; VAS, Visual Analog Scale; \%, percentage predicted.

${ }^{\star}$ Evaluated in IPF.

${ }^{\dagger}$ Results for cough domains quoted.

${ }^{\ddagger}$ Results expressed as range of means for United Kingdom and United States of America populations.

Results expressed as mean \pm standard deviation or mean \pm standard error.

\section{Patient Reported Outcome Measures (PROMs)}

Patient reported outcomes (PROs) have gained importance in recognition of their value to capture patients' perceptions of their symptoms and health status. They are measured using standardized questionnaires, which may be generic, diseasespecific, or symptom-specific. PROMs for cough have been developed in other conditions such as lung cancer, while no cough-specific instruments have been developed and validated prospectively in the IPF population. The currently used cough questionnaires were developed in patients with chronic cough and other respiratory conditions such as chronic obstructive pulmonary disease. Instead of comprehensively reporting on all PROMs for cough that have been used in IPF, this review focuses on selected commonly used cough-specific instruments, including the VAS, LCQ (75), Cough Quality of Life Questionnaire (CQLQ) (76), and Cough and Sputum Assessment Questionnaire (CASA-Q) (76) (Table 2).

\section{Cough Severity Visual Analog Scale}

VAS subjectively assesses cough severity and is popular due to its simplicity. Patients are asked to place a vertical mark on a 0$100-\mathrm{mm}$ linear scale reflecting their cough intensity or frequency, with higher scores indicating greater severity. It can be used to assess both the status and changes in cough severity. There is limited robust data on its reliability and validity in specific 
respiratory conditions, including asthma and chronic obstructive pulmonary disease (84). The VAS is a responsive outcome measure in patients with acute cough (85) and when used as an outcome measure in intervention studies of chronic cough (86). Elevated VAS score predicts persistent anxiety and depression in IPF (87). However, in a recent study of patients with ILD, the VAS could not detect a change in cough symptoms (88). Further research is needed to validate VAS for cough measurement in patients with IPF.

\section{Leicester Cough Questionnaire}

The LCQ is the most widely used validated cough instrument in clinical and research settings. Its advantages are that it is relatively easy to administer, translated into many languages, and used in many cultures. It is a self-administered questionnaire consisting of 19 items covering three health domains (physical, psychological, and social) using a 7-point Likert response scale for each item. The total LCQ score ranges from 3 to 21, with lower scores indicating greater impairment in health status because of cough. All domains of the LCQ inversely correlate with objective daytime cough frequency (11) in patients with IPF. The established minimally important difference for the total LCQ score in patients with chronic cough is 1.3 points (89), which is yet to be determined in the IPF population.

\section{Cough Quality of Life Questionnaire}

The CQLQ consists of 28 items and six health domains (physical complaints, extreme physical complaints, psychosocial issues, emotional well-being, personal safety fears, and functional abilities). Each item is rated using a 4-point Likert scale. The CQLQ has good internal consistency in IPF but this does not apply to all domains (78). Internal consistency is low for both the extreme physical complaints and the personal safety fears domains. Compared to the LCQ, the CQLQ contains more items related to physical impact of cough and concerns about having a serious undiagnosed underlying cause of cough, the latter of which is irrelevant in patients with an established diagnosis of
IPF (78). Early evidence on the test-retest reliability has been positive, albeit at a study interval of 15 weeks (78) as test-retest time intervals commonly range between 2 days and 2 weeks (90). The minimally important difference for the CQLQ total score is estimated between 5 and 5.7 in patients with IPF (78), in contrast with 10.58-21.89 in patients with chronic cough (91).

\section{Cough and Sputum Assessment Questionnaire}

The CASA-Q comprises four domains: symptom and impact for cough and sputum. The score for each domain ranges from 0 to 100 , and lower scores indicate worse symptoms. It has been used in landmark trials for antifibrotic therapies in IPF $(48,92)$ with well-established content validity (79); however, its reliability and responsiveness in IPF have not yet been demonstrated (93).

\section{Cough as an Outcome Measure in Clinical Trials}

Clinical trial design in IPF has historically been hampered by a lack of consensus on appropriate outcome measures to reliably assess treatment response (94). For example, cough was not identified by the medical expert Delphi process as a core outcome domain for use in clinical trials of patients with IPF and connective tissue disease-associated ILD (94). In contrast, it was nominated as a central symptom by patients in focus groups, reflecting worsening of their condition (94). Recently, cough has been acknowledged and included as a domain in the development of comprehensive health-related quality of life measures for IPF such as the Living with IPF (L-IPF) questionnaire (82) and the IPF-specific version of the St George's Respiratory Questionnaire (83). Objective cough count measured by cough frequency monitors has traditionally been used as the preferred primary endpoint in clinical trials for antitussive medications. Expert consensus recommends the combined use of subjective instruments and objective cough frequency for evaluation of cough (95), as they provide complementary information on the severity and impacts of cough.

TABLE 3 | Summary of trials of pharmacological therapy in IPF-related cough.

\begin{tabular}{|c|c|c|c|c|}
\hline References & Study design & $\begin{array}{l}\text { Number of } \\
\text { participants }\end{array}$ & Intervention & Primary endpoint \\
\hline Birring et al. (81) & $\begin{array}{l}\text { Multi-center randomized } \\
\text { double-blind placebo-controlled } \\
\text { crossover trial }\end{array}$ & 24 & $\begin{array}{l}\text { Nebulised sodium cromoglycate } \\
\text { (PA101) via nebuliser } 40 \text { mg tds } \\
\text { for } 14 \text { days }\end{array}$ & $\begin{array}{l}\text { Mean reduction in daytime objective cough } \\
\text { frequency (coughs per hour) by } 31.1 \%\end{array}$ \\
\hline Horton et al. (80) & $\begin{array}{l}\text { Randomized, double-blind, } \\
\text { placebo-controlled cross over }\end{array}$ & 24 & $\begin{array}{l}\text { Thalidomide } 50-100 \mathrm{mg} \text { daily for } \\
12 \text { weeks }\end{array}$ & $\begin{array}{l}\text { Improvement in cough-specific quality of life } \\
\text { (CQLQ) (mean difference v. placebo, }-11.4 \\
\text { [95\% Cl, }-15.7 \text { to }-7.0] ; p<0.001 \text { ) }\end{array}$ \\
\hline Lutherer et al. (96) & $\begin{array}{l}\text { Proof of concept, uncontrolled } \\
\text { single-arm study }\end{array}$ & 12 & $\begin{array}{l}\text { IFN-alpha lozenges } 150 \mathrm{IU} \text { tds } \\
\text { for } 12 \text { months }\end{array}$ & $\begin{array}{l}\text { Improvement in cough-specific quality of life } \\
(\mathrm{LCQ}) \text { in } 5 \text { of } 6 \text { participants }\end{array}$ \\
\hline van Manen et al. (26) & $\begin{array}{l}\text { Multi-center prospective } \\
\text { observational study }\end{array}$ & 43 & $\begin{array}{l}\text { Pirfenidone dosed according to } \\
\text { clinical practice for } 12 \text { weeks }\end{array}$ & $\begin{array}{l}\text { Objective } 24-\mathrm{h} \text { total cough count decreased by } \\
34 \%[95 \% \mathrm{Cl},-48 \text { to }-15] \text { at } 12 \text { weeks }\end{array}$ \\
\hline Guler et al. (97) & $\begin{array}{l}\text { Randomized, double-blind, } \\
\text { placebo-controlled cross over }\end{array}$ & 20 & $\begin{array}{l}\text { Azithromycin } 500 \text { mg three times } \\
\text { per week for } 12 \text { weeks }\end{array}$ & $\begin{array}{l}\text { No significant change in cough-specific quality } \\
\text { of life (LCQ) }\end{array}$ \\
\hline
\end{tabular}

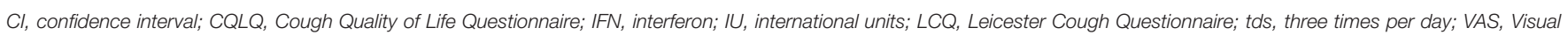
Analog Scale.

*Secondary endpoint: improvement in cough-specific quality of life measured in a subgroup of participants with chronic cough at 2-3 weeks. 


\section{THERAPIES}

There is no therapy for cough in IPF that has proved effective in clinical trials. Aside from treatment of relevant comorbidities, several therapies have been tried for chronic cough in IPF and may be useful in some individuals, which include both nonpharmacological and pharmacological interventions (Table 3). It is suggested that most antitussive interventions are trialed for 2 weeks before re-evaluation and change of therapy. For refractory cough, referral to specialized cough clinics for a trial of speech therapy or physiotherapy and neuromodulation can be considered. Patients with end-stage disease may benefit from referral to specialist palliative care for symptom control.

\section{Non-Pharmacological Multimodality Speech Therapy}

While the evidence is scarce in patients with IPF, multimodality speech therapy, an established therapy for unexplained chronic cough, may be a suitable treatment. Speech therapy has been reported to decrease cough frequency and improve quality of life in chronic cough (98). The Physiotherapy, Speech and Language Therapy Intervention has shown similar benefits in patients with chronic cough (99). These therapies include education about cough and cough control techniques, laryngeal hygiene, and psychoeducational counseling, which may be used alongside neuromodulator medications for cough reflex sensitivity such as gabapentin or pregabalin.

\section{Pharmacological}

\section{Antifibrotic Drug Therapies}

The outlook for patients with IPF changed with the availability of two antifibrotic drug therapies; nintedanib and pirfenidone. Nintedanib alters cell signaling mediated by tyrosine kinases resulting in the inhibition of mechanisms fundamental to the development of fibrosis (100). Pirfenidone exhibits pleiotropic antifibrotic, anti-inflammatory and antioxidant properties, which has recently been linked to the inhibition of glioma-associated oncogene homolog transcription factors (101). These drugs have been approved for clinical use by regulators based on their proven efficacy in slowing lung function decline. Animal studies show that pirfenidone decreases cough reflex sensitivity to capsaicin (102). In an observational study of patients with IPF and chronic cough (defined as daily cough over 8 weeks duration and with a cough score of $\geq 40 \mathrm{~mm}$ on a $0-100 \mathrm{~mm}$ VAS), pirfenidone reduced objective cough frequency and subjective cough scores measured by the LCQ and VAS at 12 weeks (26). Nintedanib does not improve cough related quality of life or symptom scores as measured by the Living with Pulmonary Fibrosis Questionnaire (103) and CASA-Q (93). Further research is needed to evaluate the therapeutic effects of existing and in-development antifibrotic drugs in future clinical trials, with cough being included as an outcome measure and assessed using validated instruments.

\section{Other Pharmacological Therapies}

Studies evaluating antitussive therapies in IPF are limited. Opioids have been shown to decrease cough frequency and improve cough-related quality of life in patients with chronic cough in a study of slow-release oral morphine at a dose of $5 \mathrm{mg}$ twice daily (77). Common side effects are constipation and drowsiness, which do not usually require drug cessation. Until further evidence is available, the recommended use of low dose morphine is restricted to advanced IPF where intractable cough impairs quality of life (63). A randomized controlled trial of low dose slow-release morphine in patients with IPF and chronic cough (NCT04429516) is currently underway.

TABLE 4 | Clinical trials under recruitment for cough in IPF.

\begin{tabular}{|c|c|c|c|c|c|}
\hline NCT trial ID & Study name & $\begin{array}{c}\text { Target recruitment } \\
\text { number }\end{array}$ & Study duration & Primary endpoints & $\begin{array}{l}\text { Projected end } \\
\text { date* }^{*}\end{array}$ \\
\hline \multirow[t]{2}{*}{ NCT04318704 } & $\begin{array}{l}\text { An Open-Label Study of the Efficacy, } \\
\text { Safety and Tolerability of NP-120 on } \\
\text { Idiopathic Pulmonary Fibrosis and Its } \\
\text { Associated Cough }\end{array}$ & 20 & 14 months & $\begin{array}{l}\text { 1. } \geq 50 \% \text { reduction in the average } \\
\text { number of coughs per hour at } 12 \\
\text { weeks compared to baseline using an } \\
\text { ambulatory cough monitor }\end{array}$ & September 2021 \\
\hline & & & & $\begin{array}{l}\text { 2. No worsening of FVC in either } \mathrm{mL} \\
\text { or } \% \text { predicted at } 12 \text { weeks } \\
\text { compared to baseline }\end{array}$ & \\
\hline NCT04030026 & $\begin{array}{l}\text { Phase 2, Double-blind, Randomized, } \\
\text { Placebo-controlled, Two-Treatment, } \\
\text { Two-Period Crossover Efficacy and } \\
\text { Safety Study in Idiopathic Pulmonary } \\
\text { Fibrosis (IPF) With Nalbuphine ER } \\
\text { Tablets for the Treatment of Cough }\end{array}$ & 60 & 16 months & $\begin{array}{l}\text { Mean daytime cough frequency } \\
\text { (coughs per hour) at day } 22 \text { using } \\
\text { objective digital cough monitoring }\end{array}$ & December 2021 \\
\hline NCT04429516 & $\begin{array}{l}\text { PAciFy Cough: A Multicentre, } \\
\text { Double-Blind, Placebo-Controlled, } \\
\text { Crossover Trial of Morphine Sulfate } \\
\text { for the Treatment of PulmonAry } \\
\text { Fibrosis Cough }\end{array}$ & 44 & 20 months & $\begin{array}{l}\text { The percentage change in daytime } \\
\text { cough frequency (coughs per hour) } \\
\text { from baseline as assessed by } \\
\text { objective digital cough monitoring at } \\
\text { Day } 14 \text { of treatment }\end{array}$ & August 2022 \\
\hline
\end{tabular}

FVC, forced vital capacity; IPF, idiopathic pulmonary fibrosis; NCT, National Clinical Trial; NP-120, Ifenprodil.

${ }^{*}$ Data obtained from a search of the National Institutes of Health (NIH) and National Library of Medicine (NLM) Clinical Trials Database (ClinicalTrials.gov) on 15 th June 2021. 
In a randomized placebo-controlled trial of 24 patients with IPF, low-dose thalidomide was shown to improve cough severity and respiratory-related quality of life measured by the CQLQ and VAS scores (80). However, $77 \%$ of patients in the treatment arm experienced drug-related adverse effects compared to $22 \%$ in the placebo arm. Hence, widespread uptake for its clinical use is limited by the unfavorable side effects, including gastrointestinal disturbance, bradycardia, thromboembolism, peripheral neuropathy, and potential for teratogenicity. Nevertheless, thalidomide may be considered if other agents are contraindicated or have failed. A phase II proof-of-concept trial showed that a novel formulation of sodium cromoglycate (PA101) given via high-efficiency nebuliser reduced mean daytime cough frequency by $31 \%$ at 14 days in patients with IPF and was generally welltolerated (81). This benefit has been shown in cough caused by angiotensin-converting enzyme inhibitors and non-small cell lung cancer (104). An older study of six patients with IPF showed therapeutic benefits of high-dose oral corticosteroids for cough (29). However, the detrimental effects of high-dose corticosteroids in IPF have since been well-described (105), and its use for this indication is now discouraged. Low-dose corticosteroids have been tried with little data to support their effectiveness. Several novel drug targets have been identified in unexplained chronic cough, including antagonists at the P2X3 sensory nerve ion channel. A randomized, double-blind, placebo-controlled trial of a P2X3 antagonist, Gefapixant, in patients with IPF and persistent cough showed initial promise, however, the primary endpoint of change in awake objective cough frequency (coughs per hour) was not met (106). Further

\section{REFERENCES}

1. Young EC, Smith JA. Quality of life in patients with chronic cough. Ther Adv Respir Dis. (2010) 4:49-55. doi: 10.1177/1753465809358249

2. Ryerson CJ, Abbritti M, Ley B, Elicker BM, Jones KD, Collard HR. Cough predicts prognosis in idiopathic pulmonary fibrosis. Respirology. (2011) 16:969-75. doi: 10.1111/j.1440-1843.2011.01996.x

3. van Manen MJG, Birring SS, Vancheri C, Odink AE, Hussain B, Vindigni V, et al. Predictors of objective cough in patients with idiopathic pulmonary fibrosis (IPF). Eur Respir J. (2019) 54:PA1729. doi: 10.1183/13993003.congress-2019.PA1729

4. Dicpinigaitis PV. Cough reflex sensitivity in cigarette smokersa. Chest. (2003) 123:685-8. doi: 10.1378/chest.123.3.685

5. Liyan C, Xiaofeng L, Kefang L. Analysis of clinical features and cough characteristics of patients with interstitial lung disease. Respirology. (2018) 23:277. doi: 10.1111/resp.13420_521

6. Cheng JZ, Wilcox PG, Glaspole I, Corte TJ, Murphy D, Hague CJ, et al. Cough is less common and less severe in systemic sclerosis-associated interstitial lung disease compared to other fibrotic interstitial lung diseases. Respirology. (2017) 22:1592-7. doi: 10.1111/resp.13084

7. Pietinalho A, Ohmichi M, Hiraga Y, Löfroos AB, Selroos O. The mode of presentation of sarcoidosis in Finland and Hokkaido, Japan. A comparative analysis of 571 Finnish and 686 Japanese patients. Sarcoidosis Vasc Diffuse Lung Dis. (1996) 13:159-66. doi: 10.1007/BF003 89839

8. Sato R, Handa T, Matsumoto H, Kubo T, Hirai T. Clinical significance of self-reported cough intensity and frequency in patients with interstitial lung disease: a cross-sectional study. BMC Pulm Med. (2019) 19:247. clinical trials of novel agents for cough in IPF are underway (Table 4).

\section{CONCLUSION}

Cough is a common and often under-recognized symptom of IPF, which is associated with disease progression. Identified as a central symptom by patients and their caregivers, cough impacts health-related quality of life. Careful and timely clinical evaluation and assessment using validated tools that objectively and subjectively measure cough in this specific patient population are recommended. Currently available measurement tools for chronic cough have been suboptimally validated in patients with IPF. The development of disease-specific PROMs for cough in the IPF population is required to accurately and reliably show the difference between competing therapies. Further clinical research into effective non-pharmacological and pharmacological interventions for cough is vital to improve symptom management and health outcomes for patients with this progressive disease. In light of the limited proven efficacy of single therapeutic agents for cough in IPF, future clinical trials may consider multimodal interventions or combination drug therapy in this patient population.

\section{AUTHOR CONTRIBUTIONS}

YK and JM conceived the presented idea. JM performed the literature search and wrote the manuscript with support and critical feedback from YK. Critical feedback was also provided by $\mathrm{NG}$ and $\mathrm{AH}$. All authors contributed to the final manuscript.

9. Rajala K, Lehto JT, Sutinen E, Kautiainen H, Myllärniemi M, Saarto T. Marked deterioration in the quality of life of patients with idiopathic pulmonary fibrosis during the last two years of life. BMC Pulm Med. (2018) 18:172. doi: 10.1186/s12890-018-0738-x

10. Van Manen M, Birring S, Vancheri C, Vindigni V, Wapenaar M, Cottin V, et al. Cough measurements in patients with idiopathic pulmonary fibrosis (IPF). In: C43 If You've got Trouble: Chronic Cough. American Thoracic Society International Conference Abstracts. Denver: American Thoracic Society (2015). p. A4422-A.

11. Key AL, Holt K, Hamilton A, Smith JA, Earis JE. Objective cough frequency in Idiopathic Pulmonary Fibrosis. Cough. (2010) 6:4. doi: 10.1186/1745-9974-6-4

12. Bajwah S, Higginson IJ, Ross JR, Wells AU, Birring SS, Riley J, et al. The palliative care needs for fibrotic interstitial lung disease: a qualitative study of patients, informal caregivers and health professionals. Palliat Med. (2013) 27:869-76. doi: 10.1177/0269216313497226

13. Lee KK, Birring SS. Cough and sleep. Lung. (2010) 188(Suppl.1):S914. doi: 10.1007/s00408-009-9176-0

14. Brignall K, Jayaraman B, Birring SS. Quality of life and psychosocial aspects of cough. Lung. (2008) 186(Suppl.1):S55-8. doi: 10.1007/s00408-007-9034-x

15. Senanayake S, Harrison, K, Lewis, M, McNarry, M, Hudson, J. patients' experiences of coping with idiopathic pulmonary fibrosis and their recommendations for its clinical management. PLoS ONE. (2018) 13:e0197660. doi: 10.1371/journal.pone.0197660

16. Sampson C, Gill BH, Harrison NK, Nelson A, Byrne A. The care needs of patients with idiopathic pulmonary fibrosis and their carers (CaNoPy): results of a qualitative study. BMC Pulm Med. (2015) 15:155. doi: 10.1186/s12890-015-0145-5 
17. McGovern AE, Short KR, Kywe Moe AA, Mazzone SB. Translational review: neuroimmune mechanisms in cough and emerging therapeutic targets. $J$ Allergy Clin Immunol. (2018) 142:1392-402. doi: 10.1016/j.jaci.2018.09.004

18. McCool FD. Global physiology and pathophysiology of cough: ACCP evidence-based clinical practice guidelines. Chest. (2006) 129(Suppl.1):4853. doi: 10.1378/chest.129.1_suppl.48S

19. Mazzone SB. Sensory regulation of the cough reflex. Pulm Pharmacol Ther. (2004) 17:361-8. doi: 10.1016/j.pupt.2004.09.021

20. Canning BJ, Mori N, Mazzone SB. Vagal afferent nerves regulating the cough reflex. Respir Physiol Neurobiol. (2006) 152:223-42. doi: 10.1016/j.resp.2006.03.001

21. Polverino M, Polverino F, Fasolino M, Andò F, Alfieri A, De Blasio F. Anatomy and neuro-pathophysiology of the cough reflex arc. Multidiscip Respir Med. (2012) 7:5. doi: 10.1186/2049-6958-7-5

22. Harrison NK. Idiopathic pulmonary fibrosis: a nervous cough? Pulm Pharmacol Ther. (2004) 17:347-50. doi: 10.1016/j.pupt.2004.09.029

23. Tatar M, Webber SE, Widdicombe JG. Lung C-fibre receptor activation and defensive reflexes in anaesthetized cats. J Physiol. (1988) 402:411-20.

24. Jones RM, Hilldrup S, Hope-Gill BD, Eccles R, Harrison NK. Mechanical induction of cough in idiopathic pulmonary fibrosis. Cough. (2011) 7:2. doi: 10.1113/jphysiol.1988.sp017212

25. Froese AR, Shimbori C, Bellaye PS, Inman M, Obex S, Fatima $S$, et al. Stretch-induced activation of transforming growth factor- $\beta 1$ in pulmonary fibrosis. Am J Respir Crit Care Med. (2016) 194:8496. doi: 10.1164/rccm.201508-16380C

26. van Manen MJG, Birring SS, Vancheri C, Vindigni V, Renzoni E, Russell A-M, et al. Effect of pirfenidone on cough in patients with idiopathic pulmonary fibrosis. Eur Respir J. (2017) 50:1701157. doi: 10.1183/13993003.01157-2017

27. Leslie KO. Idiopathic pulmonary fibrosis may be a disease of recurrent, tractional injury to the periphery of the aging lung: a unifying hypothesis regarding etiology and pathogenesis. Arch Pathol Lab Med. (2012) 136:591600. doi: 10.5858/arpa.2011-0511-OA

28. Doherty MJ, Mister R, Pearson MG, Calverley PMA. Capsaicin induced cough in cryptogenic fibrosing alveolitis. Thorax. (2000) 55:1028-32. doi: 10.1136/thorax.55.12.1028

29. Hope-Gill BD, Hilldrup S, Davies C, Newton RP, Harrison NK. A study of the cough reflex in idiopathic pulmonary fibrosis. Am J Respir Crit Care Med. (2003) 168:995-1002. doi: 10.1164/rccm.200304-597OC

30. Jones RM. Studies on the Pathogenesis of the Cough Reflex in Idiopathic Pulmonary Fibrosis. Swansea: University of Swansea.

31. Birring SS, Parker D, McKenna S, Hargadon B, Brightling CE, Pavord ID, et al. Sputum eosinophilia in idiopathic pulmonary fibrosis. Inflamm Res. (2005) 54:51-6. doi: 10.1007/s00011-004-1321-x

32. Bargagli E, Di Masi M, Perruzza M, Vietri L, Bergantini L, Torricelli E, et al. The pathogenetic mechanisms of cough in idiopathic pulmonary fibrosis. Intern Emerg Med. (2019) 14:39-43. doi: 10.1007/s11739-018-1960-5

33. Lee MG, Lee YH. A meta-analysis examining the association between the MUC5B rs35705950 T/G polymorphism and susceptibility to idiopathic pulmonary fibrosis. Inflamm Res. (2015) 64:463-70. doi: 10.1007/s00011-015-0829-6

34. Wei R, Li C, Zhang M, Jones-Hall YL, Myers JL, Noth I, et al. Association between MUC5B and TERT polymorphisms and different interstitial lung disease phenotypes. Transl Res. (2014) 163:494-502. doi: 10.1016/j.trsl.2013.12.006

35. Horimasu Y, Ohshimo S, Bonella F, Tanaka S, Ishikawa N, Hattori N, et al. MUC5B promoter polymorphism in Japanese patients with idiopathic pulmonary fibrosis. Respirology. (2015) 20:439-44. doi: 10.1111/resp.12466

36. Scholand MB, Wolff R, Crossno PF, Sundar K, Winegar M, Whipple S, et al. Severity of cough in idiopathic pulmonary fibrosis is associated with MUC5 B genotype. Cough. (2014) 10:3. doi: 10.1186/1745-9974-10-3

37. Raghu G, Amatto VC, Behr J, Stowasser S. Comorbidities in idiopathic pulmonary fibrosis patients: a systematic literature review. Eur Respir J. (2015) 46:1113-30. doi: 10.1183/13993003.02316-2014

38. Collard HR, Ward AJ, Lanes S, Cortney Hayflinger D, Rosenberg DM, Hunsche E. Burden of illness in idiopathic pulmonary fibrosis. J Med Econ. (2012) 15:829-35. doi: 10.3111/13696998.2012.680553
39. Daniels CE, Jett JR. Does interstitial lung disease predispose to lung cancer? Curr Opin Pulm Med. (2005) 11:4317. doi: 10.1097/01.mcp.0000170521.71497.ba

40. Khor YH, Ryerson CJ, Landry SA, Howard ME, Churchward TJ, Edwards BA, et al. Interstitial lung disease and obstructive sleep apnea. Sleep Med Rev. (2021) 58:101442. doi: 10.1016/j.smrv.2021.101442

41. Jo HE, Corte TJ, Glaspole I, Grainge C, Hopkins PMA, Moodley $\mathrm{Y}$, et al. Gastroesophageal reflux and antacid therapy in IPF: analysis from the Australia IPF Registry. BMC Pulm Med. (2019) 19:84. doi: 10.1186/s12890-019-0846-2

42. D’Ovidio F, Singer LG, Hadjiliadis D, Pierre A, Waddell TK, de Perrot M, et al. Prevalence of gastroesophageal reflux in end-stage lung disease candidates for lung transplant. Ann Thorac Surg. (2005) 80:125460. doi: 10.1016/j.athoracsur.2005.03.106

43. Han MK. High prevalence of abnormal acid gastro-oesophageal reflux in idiopathic pulmonary fibrosis. Eur Respir J. (2006) 28:884-5 doi: 10.1183/09031936.06.00071806

44. Kilduff CE, Counter MJ, Thomas GA, Harrison NK, Hope-Gill BD. Effect of acid suppression therapy on gastroesophageal reflux and cough in idiopathic pulmonary fibrosis: an intervention study. Cough. (2014) 10:4. doi: 10.1186/1745-9974-10-4

45. Grabczak EM, Stec S, Dabrowska M, Plevkova J, Krenke R. Cough as a cause and consequence of heart dysfunction - current state of art. Physiol Res. (2020) 69:S105-21. doi: 10.33549/physiolres.934408

46. Chung MJ, Goo JM, Im JG. Pulmonary tuberculosis in patients with idiopathic pulmonary fibrosis. Eur J Radiol. (2004) 52:175-9. doi: 10.1016/j.ejrad.2003.11.017

47. Orrego CM, Cordero-Reyes AM, Estep JD, Seethamraju H, Scheinin S, Loebe $\mathrm{M}$, et al. Atrial arrhythmias after lung transplant: underlying mechanisms, risk factors, and prognosis. J Heart Lung Transplant. (2014) 33:73440. doi: 10.1016/j.healun.2014.02.032

48. King TE, Bradford WZ, Castro-Bernardini S, Fagan EA, Glaspole I, Glassberg $\mathrm{MK}$, et al. A phase 3 trial of pirfenidone in patients with idiopathic pulmonary fibrosis. N Engl J Med. (2014) 370:208392. doi: 10.1056/NEJMoa1402582

49. Noble PW, Albera C, Bradford WZ, Costabel U, Glassberg MK, Kardatzke D, et al. Pirfenidone in patients with idiopathic pulmonary fibrosis (CAPACITY): two randomised trials. Lancet. (2011) 377:17609. doi: 10.1016/S0140-6736(11)60405-4

50. Kreuter M, Lederer DJ, Molina-Molina M, Noth I, Valenzuela C, Frankenstein L, et al. Association of angiotensin modulators with the course of idiopathic pulmonary fibrosis. Chest. (2019) 156:70614. doi: 10.1016/j.chest.2019.04.015

51. Kreuter M, Ehlers-Tenenbaum S, Palmowski K, Bruhwyler J, Oltmanns U, Muley $\mathrm{T}$, et al. Impact of comorbidities on mortality in patients with idiopathic pulmonary fibrosis. PLoS ONE. (2016) 11:e0151425. doi: 10.1371/journal.pone.0151425

52. Kreuter M, Wuyts W, Renzoni E, Koschel D, Maher TM, Kolb $\mathrm{M}$, et al. Antacid therapy and disease outcomes in idiopathic pulmonary fibrosis: a pooled analysis. Lancet Respir Med. (2016) 4:381-9. doi: 10.1016/S2213-2600(16)00067-9

53. Mackintosh JA, Desai SR, Adamali H, Patel K, Chua F, Devaraj A, et al. In patients with idiopathic pulmonary fibrosis the presence of hiatus hernia is associated with disease progression and mortality. Eur Respir J. (2019) 53:1802412. doi: 10.1183/13993003.02412-2018

54. Ghebre YT, Raghu G. Idiopathic pulmonary fibrosis: novel concepts of proton pump inhibitors as antifibrotic drugs. Am J Respir Crit Care Med. (2016) 193:1345-52. doi: 10.1164/rccm.201512-2316PP

55. Gao F, Hobson AR, Shang ZM, Pei YX, Gao Y, Wang JX, et al. The prevalence of gastro-esophageal reflux disease and esophageal dysmotility in Chinese patients with idiopathic pulmonary fibrosis. BMC Gastroenterol. (2015) 15:26. doi: 10.1186/s12876-015-0253-y

56. Hershcovici T, Jha LK, Johnson T, Gerson L, Stave C, Malo J, et al. Systematic review: the relationship between interstitial lung diseases and gastro-oesophageal reflux disease. Aliment Pharmacol Ther. (2011) 34:1295305. doi: 10.1111/j.1365-2036.2011.04870.x 
57. Popper H, Juettner F, Pinter J. The gastric juice aspiration syndrome (Mendelson syndrome). Virchows Archiv A. (1986) 409:105-17. doi: 10.1007/BF00705410

58. Qiu Z, Yu L, Xu S, Liu B, Zhao T, Lu H, et al. Cough reflex sensitivity and airway inflammation in patients with chronic cough due to non-acid gastro-oesophageal reflux. Respirology. (2011) 16:64552. doi: 10.1111/j.1440-1843.2011.01952.x

59. Crooks MG, Dudziak J, Morice AH, Hart SP. Cough in idiopathic pulmonary fibrosis: a sign of "silent" gastroesophageal reflux. In: A45 For Your Eyes Only: But Everyone Will Hear the Chronic Cough. American Thoracic Society International Conference Abstracts. San Diego, CA: American Thoracic Society (2014). p. A1613-A.

60. Gavini S, Borges LF, Finn RT, Lo WK, Goldberg HJ, Burakoff R, et al. Lung disease severity in idiopathic pulmonary fibrosis is more strongly associated with impedance measures of bolus reflux than $\mathrm{pH}$ parameters of acid reflux alone. Neurogastroenterol Motil. (2017) 29:13001. doi: 10.1111/nmo.13001

61. Fossmark R, Martinsen TC, Waldum HL. Adverse effects of proton pump inhibitors-evidence and plausibility. Int J Mol Sci. (2019) 20:5203. doi: 10.3390/ijms20205203

62. Almario CV, Chey WD, Spiegel BMR. Increased risk of COVID-19 among users of proton pump inhibitors. Am J Gastroenterol. (2020) 115170715. doi: 10.14309 /ajg.0000000000000798

63. Birring SS, Kavanagh JE, Irwin RS, Keogh KA, Lim KG, Ryu $\mathrm{JH}$, et al. Treatment of interstitial lung disease associated cough: chest guideline and expert panel report. Chest. (2018) 154:904-17. doi: 10.1016/j.chest.2018.06.038

64. Ancoli-Israel S, Gehrman P, Kripke DF, Stepnowsky C, Mason W, CohenZion $\mathrm{M}$, et al. Long-term follow-up of sleep disordered breathing in older adults. Sleep Med. (2001) 2:511-6. doi: 10.1016/S1389-9457(00)00096-4

65. Peppard PE, Young T, Barnet JH, Palta M, Hagen EW, Hla KM. Increased prevalence of sleep-disordered breathing in adults. Am J Epidemiol. (2013) 177:1006-14. doi: 10.1093/aje/kws342

66. Birring SS, Ing AJ, Chan K, Cossa G, Matos S, Morgan MD, et al. Obstructive sleep apnoea: a cause of chronic cough. Cough. (2007) 3:7. doi: 10.1186/1745-9974-3-7

67. Mermigkis C, Bouloukaki I, Antoniou KM, Mermigkis D, Psathakis K, Giannarakis I, et al. CPAP therapy in patients with idiopathic pulmonary fibrosis and obstructive sleep apnea: does it offer a better quality of life and sleep? Sleep Breath. (2013) 17:1137-43. doi: 10.1007/s11325-013-08 13-8

68. Mermigkis C, Mermigkis D, Varouchakis G, Schiza S. CPAP treatment in patients with idiopathic pulmonary fibrosis and obstructive sleep apnea-therapeutic difficulties and dilemmas. Sleep Breath. (2012) 16:13. doi: 10.1007/s11325-010-0476-7

69. Mermigkis C, Bouloukaki I, Antoniou K, Papadogiannis G, Giannarakis I, Varouchakis G, et al. Obstructive sleep apnea should be treated in patients with idiopathic pulmonary fibrosis. Sleep Breath. (2015) 19:38591. doi: 10.1007/s11325-014-1033-6

70. Birring SS, Fleming T, Matos S, Raj AA, Evans DH, Pavord ID. The Leicester Cough Monitor: preliminary validation of an automated cough detection system in chronic cough. Eur Respir J. (2008) 31:10138. doi: 10.1183/09031936.00057407

71. McGuinness K, Holt K, Dockry R, Smith J. P159 Validation of the vitaloJAK ${ }^{\mathrm{TM}} 24$ hour ambulatory cough monitor. Thorax. (2012) 67(Suppl.2):A131-A. doi: 10.1136/thoraxjnl-2012-202678.220

72. Nieto L, de Diego A, Perpiñá M, Compte L, Garrigues V, Martínez E, et al. Cough reflex testing with inhaled capsaicin in the study of chronic cough. Respir Med. (2003) 97:393-400. doi: 10.1053/rmed.2002.1460

73. Morice AH, Fontana GA, Belvisi MG, Birring SS, Chung KF, Dicpinigaitis PV, et al. ERS guidelines on the assessment of cough. Eur Respir J. (2007) 29:1256-76. doi: 10.1183/09031936.00101006

74. Cho PSP, Birring SS, Fletcher HV, Turner RD. Methods of cough assessment. J Allergy Clin Immunol Pract. (2019) 7:1715-23. doi: 10.1016/j.jaip.2019.01.049

75. Birring SS, Prudon B, Carr AJ, Singh SJ, Morgan MDL, Pavord ID. Development of a symptom specific health status measure for patients with chronic cough: leicester Cough Questionnaire (LCQ). Thorax. (2003) 58:339-43. doi: 10.1136/thorax.58.4.339
76. French CT, Irwin RS, Fletcher KE, Adams TM. Evaluation of a cough-specific quality-of-life questionnaire. Chest. (2002) 121:1123-31. doi: 10.1378/chest.121.4.1123

77. Morice AH, Menon MS, Mulrennan SA, Everett CF, Wright C, Jackson J, et al. Opiate therapy in chronic cough. Am J Respir Crit Care Med. (2007) 175:312-5. doi: 10.1164/rccm.200607-892OC

78. Lechtzin N, Hilliard ME, Horton MR. Validation of the cough quality-of-life questionnaire in patients with idiopathic pulmonary fibrosis. Chest. (2013) 143:1745-9. doi: 10.1378/chest.12-2870

79. Gries KS, Esser D, Wiklund I. Content validity of CASA-Q cough domains and UCSD-SOBQ for use in patients with idiopathic pulmonary fibrosis. Glob J Health Sci. (2013) 5:131-41. doi: 10.5539/gjhs.v5n6p131

80. Horton MR, Santopietro V, Mathew L, Horton KM, Polito AJ, Liu $\mathrm{MC}$, et al. Thalidomide for the treatment of cough in idiopathic pulmonary fibrosis: a randomized trial. Ann Intern Med. (2012) 157:398406. doi: 10.7326/0003-4819-157-6-201209180-00003

81. Birring SS, Wijsenbeek MS, Agrawal S, van den Berg JWK, Stone H, Maher TM, et al. A novel formulation of inhaled sodium cromoglicate (PA101) in idiopathic pulmonary fibrosis and chronic cough: a randomised, doubleblind, proof-of-concept, phase 2 trial. Lancet Respir Med. (2017) 5:80615. doi: 10.1016/S2213-2600(17)30310-7

82. Swigris JJ, Andrae DA, Churney T, Johnson N, Scholand MB, White ES, et al. Development and initial validation analyses of the living with idiopathic pulmonary fibrosis questionnaire. Am J Respir Crit Care Med. (2020) 202:1689-97. doi: 10.1164/rccm.202002-0415OC

83. Prior TS, Hoyer N, Shaker SB, Davidsen JR, Yorke J, Hilberg O, et al. Validation of the IPF-specific version of St. George's Respiratory Questionnaire. Respir Res. (2019) 20:199. doi: 10.1186/s12931-019-1169-9

84. Brightling CE, Monterio W, Green RH, Parker D, Morgan MDL, Wardlaw AJ, et al. Induced sputum and other outcome measures in chronic obstructive pulmonary disease: safety and repeatability. Respir Med. (2001) 95:9991002. doi: 10.1053/rmed.2001.1195

85. Lee KK, Matos S, Evans DH, White P, Pavord ID, Birring SS, et al. Longitudinal assessment of acute cough. Am J Respir Crit Care Med. (2013) 187:991-7. doi: 10.1164/rccm.201209-1686OC

86. Birring SS, Passant C, Patel RB, Prudon B, Murty GE, Pavord ID. Chronic tonsillar enlargement and cough: preliminary evidence of a novel and treatable cause of chronic cough. Eur Respir J. (2004) 23:199201. doi: 10.1183/09031936.03.00066403

87. Glaspole IN, Watson AL, Allan H, Chapman S, Cooper WA, Corte $\mathrm{TJ}$, et al. Determinants and outcomes of prolonged anxiety and depression in idiopathic pulmonary fibrosis. Eur Respir J. (2017) 50:1700168. doi: 10.1183/13993003.00168-2017

88. Yates H, Adamali HI, Maskell N, Barratt S, Sharp C. Visual analogue scales for interstitial lung disease: a prospective validation study. QJM. (2018) 111:531-9. doi: 10.1093/qjmed/hcy102

89. Raj AA, Pavord DI, Birring SS. Clinical cough IV:what is the minimal important difference for the leicester cough questionnaire? Handb Exp Pharmacol. (2009) (187):311-20. doi: 10.1007/978-3-540-79842-2_16

90. Marx RG, Menezes A, Horovitz L, Jones EC, Warren RF. A comparison of two time intervals for test-retest reliability of health status instruments. J Clin Epidemiol. (2003) 56:730-5. doi: 10.1016/S0895-4356(03)00084-2

91. Fletcher KE, French CT, Irwin RS, Corapi KM, Norman GR. A prospective global measure, the punum ladder, provides more valid assessments of quality of life than a retrospective transition measure. J Clin Epidemiol. (2010) 63:1123-31. doi: 10.1016/j.jclinepi.2009.09.015

92. Richeldi L, du Bois RM, Raghu G, Azuma A, Brown KK, Costabel U, et al. Efficacy and safety of nintedanib in idiopathic pulmonary fibrosis. $N$ Engl J Med. (2014) 370:2071-82. doi: 10.1056/NEJMoa1402584

93. Kreuter M, Wuyts WA, Wijsenbeek M, Bajwah S, Maher TM, Stowasser $S$, et al. Health-related quality of life and symptoms in patients with IPF treated with nintedanib: analyses of patient-reported outcomes from the INPULSIS ${ }^{\circledR}$ trials. Respir Res. (2020) 21:36. doi: 10.1186/s12931-020-1298-1

94. Saketkoo LA, Mittoo S, Huscher D, Khanna D, Dellaripa PF, Distler $\mathrm{O}$, et al. Connective tissue disease related interstitial lung diseases and idiopathic pulmonary fibrosis: provisional core sets of domains and instruments for use in clinical trials. Thorax. (2014) 69:42836. doi: 10.1136/thoraxjnl-2013-204202 
95. Boulet L-P, Coeytaux RR, McCrory DC, French CT, Chang AB, Birring SS, et al. Tools for assessing outcomes in studies of chronic cough: CHEST guideline and expert panel report. Chest. (2015) 147:804-14.

96. Lutherer LO, Nugent KM, Schoettle BW, Cummins MJ, Raj R, Birring SS, et al. Low-dose oral interferon $\alpha$ possibly retards the progression of idiopathic pulmonary fibrosis and alleviates associated cough in some patients. Thorax. (2011) 66:446. doi: 10.1136/thx.2010.135947

97. Guler SA, Clarenbach C, Brutsche M, Hostettler K, Brill AK, Schertel A, et al. Azithromycin for the treatment of chronic cough in idiopathic pulmonary fibrosis: a randomized controlled cross-over trial. Ann Am Thorac Soc. (2021). doi: 10.1513/AnnalsATS.202103-266OC

98. Birring SS, Floyd S, Reilly CC, Cho PSP. Physiotherapy and Speech and Language therapy intervention for chronic cough. Pulm Pharmacol Ther. (2017) 47:84-7. doi: 10.1016/j.pupt.2017.04.001

99. Patel AS, Watkin G, Willig B, Mutalithas K, Bellas H, Garrod R, et al. Improvement in health status following cough-suppression physiotherapy for patients with chronic cough. Chron Respir Dis. (2011) 8:2538. doi: 10.1177/1479972311422547

100. Wollin L, Wex E, Pautsch A, Schnapp G, Hostettler KE, Stowasser S, et al. Mode of action of nintedanib in the treatment of idiopathic pulmonary fibrosis. Eur Respir J. (2015) 45:1434-45. doi: 10.1183/09031936.00174914

101. Didiasova M, Singh R, Wilhelm J, Kwapiszewska G, Wujak L, Zakrzewicz D, et al. Pirfenidone exerts antifibrotic effects through inhibition of GLI transcription factors. FASEB J. (2017) 31:1916-28. doi: 10.1096/fj.201600892RR

102. Okazaki A, Ohkura N, Fujimura M, Katayama N, Kasahara K. Effects of pirfenidone on increased cough reflex sensitivity in guinea pigs. Pulm Pharmacol Ther. (2013) 26:603-8. doi: 10.1016/j.pupt.2013.06.009

103. Swigris JJ, Richeldi L, Wijsenbeek M, Kreuter M, Nunes H, Suda T, et al. Effects of nintedanib on dyspnea, cough and quality of life in patients with progressive fibrosing interstitial lung diseases: findings from the inbuild trial. In: B16 ILD THERAPY II. American Thoracic Society International Conference Abstracts. American Thoracic Society (2020). p. A2754A. doi: 10.1164/ajrccm-conference.2020.201.1_MeetingAbstracts.A2754

104. Moroni M, Porta C, Gualtieri G, Nastasi G, Tinelli C. Inhaled sodium cromoglycate to treat cough in advanced lung cancer patients. Br J Cancer. (1996) 74:309-11. doi: 10.1038/bjc.1996.358
105. The Idiopathic Pulmonary Fibrosis Clinical Research Network. Prednisone, azathioprine, and n-acetylcysteine for pulmonary fibrosis. $N$ Engl J Med. (2012) 366:1968-77. doi: 10.1056/NEJMoa1113354

106. Martinez FJ, Afzal A, Kitt MM, Ford A, Li JJ, Li YP, et al. The Treatment of chronic cough in idiopathic pulmonary fibrosis patients with gefapixant, a $\mathrm{P} 2 \times 3$ receptor antagonist. In: B17 Advances in ILD therapy. American Thoracic Society International Conference Abstracts. Dallas: American Thoracic Society (2019). p. A2638A. doi: 10.1164/ajrccm-conference.2019.199.1_MeetingAbstracts.A2638

Conflict of Interest: YK reports grants and personal fees from Boehringer Ingelheim, personal fees from Roche, other from Air Liquide Healthcare, outside the submitted work. NG reports personal fees from Boehringer Ingelheim, Roche, AstraZenaca, and Novartis, other from Air Liquide Healthcare, outside the submitted work. AH reports non-financial support from BOC Ltd Australia and Air Liquide Healthcare, outside the submitted work.

The remaining author declares that the research was conducted in the absence of any commercial or financial relationships that could be construed as a potential conflict of interest.

Publisher's Note: All claims expressed in this article are solely those of the authors and do not necessarily represent those of their affiliated organizations, or those of the publisher, the editors and the reviewers. Any product that may be evaluated in this article, or claim that may be made by its manufacturer, is not guaranteed or endorsed by the publisher.

Copyright (c) 2021 Mann, Goh, Holland and Khor. This is an open-access article distributed under the terms of the Creative Commons Attribution License (CC BY). The use, distribution or reproduction in other forums is permitted, provided the original author(s) and the copyright owner(s) are credited and that the original publication in this journal is cited, in accordance with accepted academic practice. No use, distribution or reproduction is permitted which does not comply with these terms. 